\title{
BLOOD AMMONIA LEVELS FOLLOWING THE INGESTION OF CASEIN AND WHOLE BLOOD ${ }^{1}$
}

\author{
By ALICE N. BESSMAN and GEORGE S. MIRICK with the technical assistance of \\ ROBERT HAWKINS
}

\author{
(From the Department of Medicine, Johns Hopkins University and Baltimore City Hospitals, \\ Baltimore, $M d$.)
}

(Submitted for publication February 6, 1958; accepted March 27, 1958)

In the recent past, much attention has been focused on the role of ammonia in hepatic coma. A relation between gastrointestinal bleeding and the precipitation of hepatic coma has been noted $(1,2)$. Various substances have been administered into the gastrointestinal tract, such as urea, ammonium chloride, exchange resins of the ammonia cycle, high protein feedings, and blood (3-7), all of which can produce elevated blood ammonia levels and precipitate hepatic coma in susceptible individuals. The implicit assumption, if not explicit expression, in these various studies, has been that all of these substances are more or less equally noxious agents in regard to elevating blood ammonia and causing the concomitant neurological changes. The problem of irreversible coma in patients with liver disease following gastrointestinal bleeding is frequently found; yet high protein diets are standard fare in the treatment of cirrhosis, and relatively infrequent catastrophies result. We have compared the relative effect of the ingestion of protein derived from blood as compared to protein derived from casein and milk solids (Protenum ${ }^{\circledR}$ ) on the blood ammonia and nonprotein nitrogen (NPN).

\section{METHODS}

Observations were made on a control group and a group of patients with liver disease. The control group consisted of three patients with cerebrovascular accidents and generalized arteriosclerosis but no demonstrable liver disease, and one patient with anxiety neurosis and no demonstrable liver disease. Of the patients with liver disease, six had Laennec's cirrhosis and one had diffuse carcinomatosis with hepatic involvement.

In the control group two patients were given both blood and Protenum ${ }^{\circledR}$ at different times. In these patients the total amount of protein nitrogen administered in the blood and Protenum ${ }^{\circledR}$ was the same. A third control patient received only blood and the fourth con-

\footnotetext{
1 Supported by a grant from the United States Public Health Service, National Heart Institute.
}

trol patient received only Protenum ${ }^{\circledR}$. All patients with liver disease received both blood and Protenum ${ }^{\circledR}$, at suitable intervals, at times when they were considered to be relatively stable in regard to their liver disease. Four patients received Protenum ${ }^{\circledR}$ first and three patients received the blood first. F. G., R. V., E. B. and C. D. ingested Protenum ${ }^{\circledR}$ first.

The blood used for intragastric administration was blood collected under standard blood bank conditions and kept refrigerated until used. Prior to administration aliquot specimens of the bottles of blood from the blood bank were assayed in duplicate for total nitrogen by the macro-Kjeldahl method (8). Total nitrogen in weighed samples of Protenum was similarly measured. $\mathrm{Cn}$ the basis of these determinations suspensions of weighed amounts of Protenum $\otimes$ could be made equivalent in volume and nitrogen content to any given quantity of the bank blood. Protenum ${ }^{\circledR}$ is made from nonfat milk solids, calcium caseinate, dextrose, cocoa, vitamins and minerals [by analysis, the protein content $(\mathrm{N} \times 6.38)$ is 42 per cent by weight, according to the manufacturer].

All patients were in a fasting state. After initial blood specimens were taken, they received the blood or Protenum in approximately the same amount of total fluid containing the same quanitity of total nitrogen, over a 20 to 30 minute period of time, via nasal tube or by ingestion. Arterial and venous blood samples were drawn simultaneously whenever feasible at $0,1,2.5,4$ and 5 hours after administration of the test substance. The patients were observed for any development of nervousness, tremors, and so forth. The blood samples were analyzed for ammonia and NPN content. A modification of the method of Seligson and Seligson (9) was used for ammonia determinations. Normal values for blood ammonia levels in our laboratory range from 0.60 to $1.10 \mu \mathrm{g}$. per $\mathrm{ml}$. The values are expressed as $\mu \mathrm{g}$. of ammonia nitrogen per $\mathrm{ml}$. NPN's were determined by the method of Folin and $\mathrm{Wu}(10)$.

\section{RESULTS}

Table I presents the results of the protein analysis of the various blood specimens which are administered to the patients. As can be seen from the data there is a wide variation in the protein concentration of the various blood specimens, all of which were drawn in the usual fashion at a 
blood bank. The highest protein content is found in the blood given Patient F. S., $20.60 \mathrm{Gm}$. per cent (Table I); the lowest is seen in that given Patient L. V., $12.31 \mathrm{Gm}$. per cent. The other values are fairly equally distributed between the two extremes. Thus it can be seen that $500 \mathrm{ml}$. of the $20.60 \mathrm{Gm}$. per cent blood would contain 103 $\mathrm{Gm}$. of protein, while an equivalent quantity of the blood given Patient L. V. would contain only approximately $62 \mathrm{Gm}$.- a 40 per cent difference.

In Table II are presented the clinical diagnoses on the various patients and some of the criteria employed to evaluate the presence and extent of liver disease. The patients with cirrhosis were studied at a time during which it was felt that their liver disease was quiescent and stable. R. S., the patient with carcinomatosis, showed a slow but steady downhill course during the study. In this case the blood was given first. Therefore, if there were any difference in liver function between the two studies it would have been slightly better when the blood was given than when the Protenum ${ }^{\circledR}$ was given. Patients with viral hepatitis or other acute liver disease were excluded from this study since it was felt that their liver disease would be in such a labile state that two studies, even only a few days apart, would not be comparable.
TABLE I

Protein content of blood administered to patients

\begin{tabular}{cc}
\hline \hline Patient & Protein \\
\hline Gm.\%
\end{tabular}

A. Patients with no liver disease
A. R.
12.50
M. K.
19.20
W. L.
18.50

B. Patients with liver disease

$\begin{array}{ll}\text { F. S. } & 20.60^{*} \\ \text { F. G. } & 19.00 \\ \text { L. V. } & 12.31 \dagger \\ \text { R. S. } & 16.10 \\ \text { R. V. } & 16.56 \\ \text { E. B. } & 13.75 \\ \text { C. D. } & 17.50\end{array}$

* Highest protein content.

$\dagger$ Lowest protein content.

Table III presents the levels of arterial and venous blood ammonia over a five hour period following the intragastric administration of approximately $500 \mathrm{ml}$. of whole bank blood, given in a period of 15 to 20 minutes. It can be seen (III, A) that the fasting blood ammonia of control patients ranged very closely around $1 \mu \mathrm{g}$. per $\mathrm{ml}$. The arteriovenous differences were very close to zero. The maximum rise of the blood ammonia level was

TABLE II

Liver function studies

\begin{tabular}{|c|c|c|c|c|c|c|c|c|c|c|c|}
\hline Patient & Diagnosis & Ascites & $\begin{array}{l}\text { Hepato- } \\
\text { megaly }\end{array}$ & $\begin{array}{l}\text { Cephalin } \\
\text { floccu- } \\
\text { lation }\end{array}$ & Thymol & $\begin{array}{c}\text { Bili- } \\
\text { rubin }\end{array}$ & $\begin{array}{l}\text { Brom- } \\
\text { sulph- } \\
\text { alein }\end{array}$ & $\begin{array}{l}\text { Total } \\
\text { protein }\end{array}$ & $\begin{array}{l}\text { Albumin' } \\
\text { globulin }\end{array}$ & $\begin{array}{l}\text { Hema- } \\
\text { tocrit }\end{array}$ & Biopsy \\
\hline A. $R$. & $\begin{array}{l}\text { Cerebral } \\
\text { vascular } \\
\text { accident }\end{array}$ & 0 & 0 & $1+$ & 0.25 & $<1.0$ & $\%$ & 5.8 & $3.6 / 2.2$ & 36 & \\
\hline M. K. & $\begin{array}{l}\text { Cerebral } \\
\text { vascular } \\
\text { accident }\end{array}$ & 0 & 0 & $2+$ & 0.80 & & & 6.6 & $3.9 / 2.7$ & 47 & \\
\hline W. L. & $\begin{array}{l}\text { Cerebral } \\
\text { vascular } \\
\text { accident }\end{array}$ & 0 & 0 & $1+$ & 0.50 & $<1.0$ & & & & 41 & \\
\hline R. Mc. & $\begin{array}{l}\text { Anxiety } \\
\text { neurosis }\end{array}$ & 0 & 0 & $1+$ & 1.0 & & $<5$ & & & 43 & \\
\hline \multicolumn{12}{|c|}{ Liver disease } \\
\hline $\begin{array}{l}\text { F.S. } \\
\text { F. G. }\end{array}$ & $\begin{array}{l}\text { Cirrhosis } \\
\text { Cirrhosis; } \\
\text { pul. tbc. }\end{array}$ & $+\underset{0}{++}$ & $\begin{array}{l}3+ \\
4+\end{array}$ & $\begin{array}{l}3+ \\
2+\end{array}$ & $\begin{array}{l}4.0 \\
1.0\end{array}$ & $\begin{array}{l}2.7 \\
3.4\end{array}$ & & $\begin{array}{l}7.9 \\
6.9\end{array}$ & $\begin{array}{l}3.5 / 4.4 \\
2.6 / 4.3\end{array}$ & 30 & + \\
\hline L. V. & Cirrhosis & 0 & $2+$ & $4+$ & & 7.3 & & 7.4 & $1.9 / 5.5$ & 42 & \\
\hline R. S. & $\begin{array}{l}\text { Carcinomatosis } \\
\text { with liver } \\
\text { involve. }\end{array}$ & 0 & $4+$ & $4+$ & 1.0 & 2.5 & & 5.9 & $3.2 / 2.7$ & 26 & + \\
\hline R. V. & Cirrhosis & + & $3+$ & $4+$ & 3.7 & 4.3 & & 7.1 & $3.3 / 3.8$ & 31 & + \\
\hline E. B. & Cirrhosis & 0 & $2+$ & $1+$ & 2.3 & 3.0 & 12.5 & 6.4 & $3.9 / 2.5$ & 42 & \\
\hline C. D. & Cirrhosis & 0 & $2+$ & $1+$ & 2.0 & 1.5 & 10.0 & 6.1 & $3.6 / 2.5$ & 43 & + \\
\hline
\end{tabular}


TABLE III

Ammonia levels following whole blood administration ( $\mu$ g. per ml.)

\begin{tabular}{|c|c|c|c|c|c|c|c|c|c|c|c|c|c|c|c|c|}
\hline \multirow[b]{2}{*}{ Patient } & \multirow{2}{*}{$\begin{array}{l}\text { Protein } \\
\text { received }\end{array}$} & \multicolumn{3}{|c|}{ Fasting } & \multicolumn{3}{|c|}{1 hour } & \multicolumn{3}{|c|}{2.5 hours } & \multicolumn{3}{|c|}{4 hours } & \multicolumn{3}{|c|}{5 hours } \\
\hline & & A & $\mathrm{V}$ & A-V & A & $\mathrm{V}$ & A-V & A & $\mathrm{V}$ & A-V & A & $\mathrm{V}$ & $\mathrm{A}-\mathrm{V}$ & $\mathrm{A}$ & $\mathrm{V}$ & A.V \\
\hline \multicolumn{17}{|c|}{$\begin{array}{l}G m \text {. } \\
\text { A. Patients with no liver disease }\end{array}$} \\
\hline A. $\mathbf{R}$. & 63 & 1.03 & 1.03 & 0.00 & 1.28 & 1.06 & +0.22 & 1.07 & 1.00 & +0.07 & 1.10 & 1.30 & -0.20 & 1.10 & 0.89 & +0.21 \\
\hline M. K. & 86 & 0.85 & 0.79 & +0.06 & 0.92 & 1.10 & -0.18 & 0.96 & 1.06 & -0.10 & 0.82 & 1.10 & -0.28 & 1.16 & 1.04 & +0.12 \\
\hline W. L. & 91 & 0.76 & 0.69 & +0.07 & 0.86 & 1.34 & -0.48 & 1.20 & 1.38 & -0.18 & 0.75 & 0.95 & -0.20 & 0.88 & 1.00 & -0.12 \\
\hline Average & 80 & 0.88 & 0.83 & +0.04 & 1.02 & 1.17 & -0.15 & 1.08 & 1.15 & -0.07 & 0.89 & 1.12 & -0.23 & 1.05 & 0.98 & +0.07 \\
\hline \multicolumn{17}{|c|}{ B. Patients with liver disease } \\
\hline F. S. & 103 & 2.00 & 1.54 & +0.46 & 2.52 & 1.80 & +0.72 & 3.01 & 2.20 & +0.81 & 3.00 & 2.48 & +0.52 & & 1.65 & \\
\hline F. G. & 104 & 2.09 & 1.74 & +0.35 & 3.52 & 2.46 & +1.06 & 4.60 & 4.12 & +0.48 & 4.48 & 4.28 & +0.20 & 4.72 & 4.43 & +0.29 \\
\hline L. V. & 74 & 1.38 & 1.33 & +0.05 & 2.30 & 1.76 & +0.54 & 4.00 & 3.36 & +0.64 & 3.95 & 2.77 & +1.8 & 3.00 & 2.85 & +0.15 \\
\hline R. S. & 80 & 2.00 & 1.56 & +0.44 & 2.32 & 1.98 & +0.34 & 2.83 & 2.93 & -0.10 & 3.54 & 3.62 & -0.08 & 3.34 & 3.22 & +0.12 \\
\hline R. V. & 75 & 1.94 & & & 2.60 & 2.30 & +0.30 & 4.06 & 3.38 & +0.68 & 3.92 & 3.76 & +0.16 & 3.35 & 3.25 & +0.10 \\
\hline E. B. & 80 & 1.48 & 1.36 & +0.12 & 2.00 & 1.60 & +0.40 & 2.68 & 1.90 & +0.78 & & & & & & \\
\hline C. D. & 70 & 1.16 & 1.22 & -0.06 & 1.93 & 1.46 & +0.47 & 2.36 & 1.65 & +0.71 & & & & 1.84 & 1.69 & +0.15 \\
\hline Average & 84 & 1.72 & 1.46 & +0.23 & 2.45 & 1.92 & +0.53 & 3.36 & 2.79 & +0.57 & 3.78 & 3.38 & +0.40 & 3.25 & 2.85 & +0.16 \\
\hline
\end{tabular}

seen in Patient W. L. who showed an increase of approximately $0.6 \mu \mathrm{g}$. per $\mathrm{ml}$. in both arterial and venous values. In contrast (Table III, $B$ ), the ammonia levels of the patients with liver disease rose significantly in all instances and rather abruptly in several cases. Furthermore there was a marked delay in some patients before the levels returned toward normal. In none of the patients with liver disease had the blood ammonia levels returned to normal by five hours. The most pronounced elevation of blood ammonia was seen in Patient F. G. after $104 \mathrm{Gm}$. of protein in the form of blood was administered. At 2.5, 4 and 5 hours, his ammonia levels were about $2.5 \mu \mathrm{g}$. per $\mathrm{ml}$. higher than the fasting level, and he exhibited symptoms of nausea, tremulousness and nervousness. Patient L. V., who showed an equivalent rise in blood ammonia, also manifested nervousness and irritability during the period of peak elevation. An interesting finding in Patient R. S. was the lack of a positive arteriovenous difference despite distinct elevation in ammonia levels. This phenomenon will be discussed later. Patients R. V. and E. B. showed more or less the same pattern as the first three patients. C. D. received the lowest total protein dose and clinically had rather mild cirrhosis. Nevertheless, his peak ammonia level was $1.2 \mu \mathrm{g}$. higher than the fasting

TABLE IV

Ammonia levels following Protenum ${ }^{\circledR}$ administration ( $\mu$ g. per ml.)

\begin{tabular}{|c|c|c|c|c|c|c|c|c|c|c|c|c|c|c|c|c|}
\hline \multirow[b]{2}{*}{ Patient } & \multirow{2}{*}{$\begin{array}{r}\text { Protein } \\
\text { received }\end{array}$} & \multicolumn{3}{|c|}{ Fasting } & \multicolumn{3}{|c|}{1 hour } & \multicolumn{3}{|c|}{2.5 hours } & \multicolumn{3}{|c|}{4 hours } & \multicolumn{3}{|c|}{5 hours } \\
\hline & & A & $\mathrm{V}$ & $\mathrm{A}-\mathrm{V}$ & A & $\mathrm{V}$ & A-V & A & V & $A-V$ & A & V & A-V & $\mathbf{A}$ & V & $A-V$ \\
\hline \multicolumn{17}{|c|}{$\begin{array}{l}\quad G m \text {. } \\
\text { ts with no liver disease }\end{array}$} \\
\hline A. $\mathbf{R}$. & 70 & 1.33 & 1.11 & +0.22 & 1.30 & 1.04 & +0.26 & 1.08 & 1.26 & -0.18 & 1.47 & 1.50 & -0.03 & 1.14 & 1.21 & -0.07 \\
\hline M. K. & 86 & 0.69 & 0.72 & -0.03 & 0.85 & 0.91 & --0.06 & 0.76 & 0.70 & +0.06 & 0.73 & 1.02 & -0.29 & 0.94 & 1.00 & -0.06 \\
\hline R. Mc. & 120 & 0.94 & 0.79 & +0.15 & 0.90 & 0.82 & +0.08 & 1.04 & 1.01 & +0.03 & 1.04 & 0.93 & +0.11 & & & \\
\hline Average & 90 & 0.98 & 0.87 & +0.11 & 1.01 & 0.92 & +0.09 & 0.96 & 0.99 & -0.03 & 1.08 & 1.15 & -0.07 & 1.04 & 1.10 & -0.06 \\
\hline \multicolumn{17}{|c|}{ B. Patients with liver disease } \\
\hline F. S. & 91 & 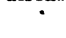 & 1.42 & & 2.34 & 1.94 & +0.62 & 2.43 & 1.94 & +0.49 & & 1.61 & & & 1.58 & \\
\hline F. G. & 120 & 1.78 & 1.40 & +0.38 & 3.35 & 2.13 & +1.22 & 2.49 & 2.33 & +0.16 & 1.92 & 1.71 & +0.21 & 2.00 & 1.58 & +0.42 \\
\hline L. V. & 74 & 1.82 & 1.75 & +0.07 & 1.82 & 1.64 & +0.18 & 2.09 & 1.90 & +0.19 & 1.81 & 1.65 & +0.16 & 1.69 & & \\
\hline R. S. & 80 & 1.22 & 1.10 & +0.12 & 1.20 & 1.16 & +0.04 & 1.50 & 1.18 & +0.32 & 1.33 & 1.09 & +0.24 & 1.49 & 1.21 & +0.28 \\
\hline R. V. & 75 & 1.53 & 1.13 & +0.40 & 2.14 & 1.23 & +0.91 & 1.69 & 1.33 & +0.36 & 1.60 & 1.13 & +0.47 & & & \\
\hline E. B. & 80 & 1.12 & 0.92 & +0.20 & 1.24 & 1.26 & -0.02 & 1.21 & 1.24 & -0.03 & & & & & & \\
\hline C. D. & 70 & 1.20 & 1.00 & +0.20 & 1.36 & 1.26 & +0.10 & 1.34 & 1.06 & +0.28 & & & & 1.53 & 1.26 & +0.27 \\
\hline Average & 84 & 1.44 & 1.24 & +0.2 .3 & 1.92 & 1.48 & +0.44 & 1.82 & 1.57 & +0.25 & 1.66 & 1.44 & +0.27 & 1.67 & 1.41 & +0.32 \\
\hline
\end{tabular}




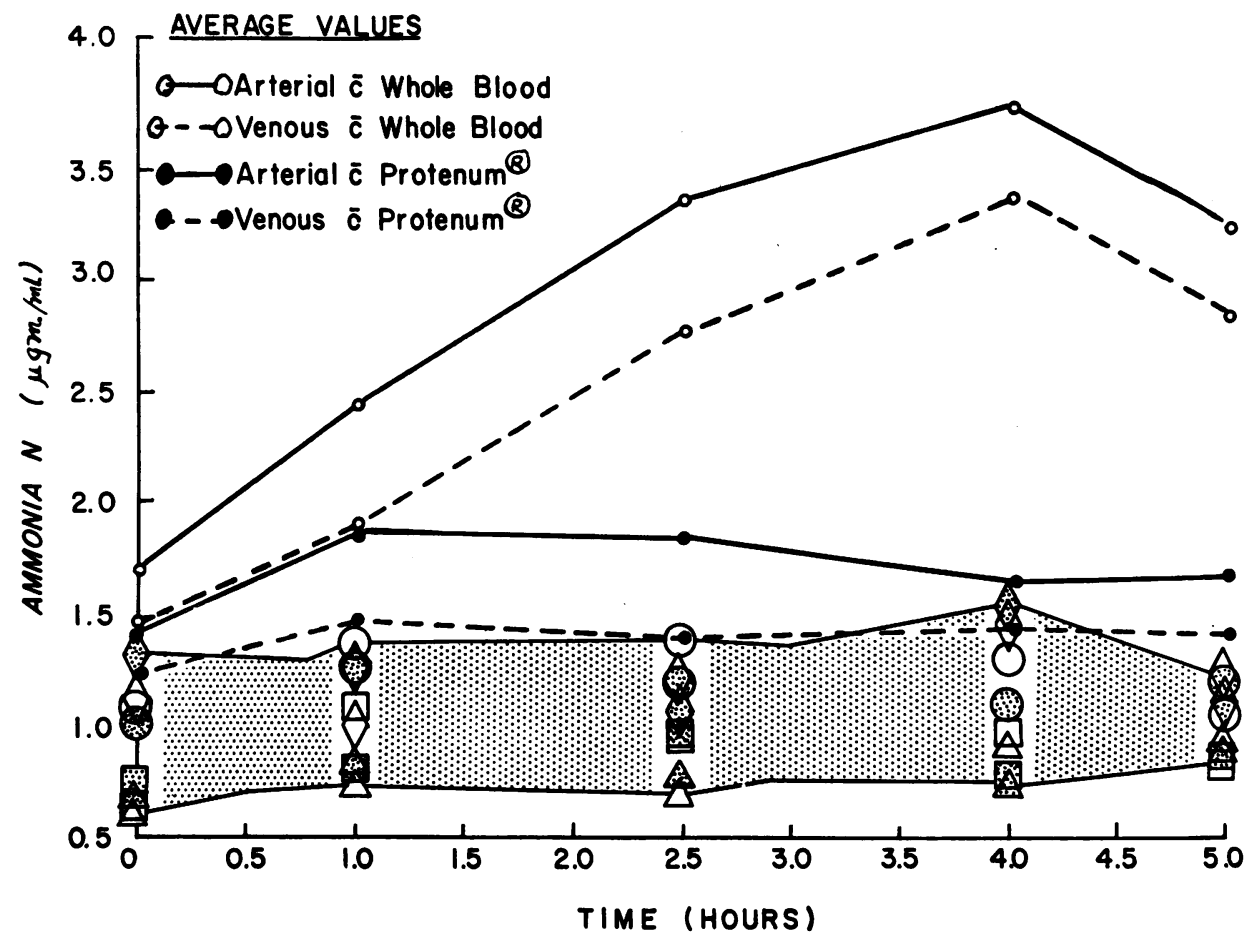

Fig. 1. Average Blood Ammonia Levels (Seven Patients) Following Administration of Blood and Protenum ${ }^{\circledR}$

Shaded area represents maximum and minimum arterial and venous blood ammonia levels of control patients similarly treated.

Stippled and open circles-maximum arterial and venous levels after blood administration; stippled and open squares-minimum arterial and venous levels after blood administration; stippled and open diamonds-maximum arterial and venous levels after Protenum ${ }^{\circledR}$ administration; stippled and open triangles-minimum arterial and venous levels after Protenum ${ }^{\circledR}$ administration.

level, an increment twice as great as the highest seen in the control group. None of the patients except F. G. and L. V. showed central nervous system symptoms during the test. It can be noted that all patients with liver disease, with the exception of $\mathrm{R}$. S., showed a positive arteriovenous difference of ammonia, and this difference usually increased parallel with the elevation of the arterial ammonia level.

Table IV gives the levels of blood ammonia in patients without liver disease (A) and with liver disease (B) following the intragastric administration of Protenum ${ }^{\circledR}$. A. R. was given slightly more protein in the Protenum ${ }^{\circledR}$ administration than in the blood administration; M. K. was given the same amount. Two other patients without liver disease were studied. W. L. was given blood containing $91 \mathrm{Gm}$. of protein (see Table III), and
R. Mc. was given $120 \mathrm{Gm}$. of protein in the form of Protenum ${ }^{\circledR}$. There were no marked changes in the blood ammonia levels in any of the normal subjects. All of the patients with liver disease received the same total amount of protein as they had received from the blood, with the exception of the first two patients. The first patient, F. S., received $12 \mathrm{Gm}$. more protein from the blood source, and $\mathrm{F}$. G. received $16 \mathrm{Gm}$. more protein as Protenum ${ }^{\circledR}$. It is of interest to note that in this latter patient (F. G.), despite the greater amount of protein received from Protenum ${ }^{\circledR}$, the elevation of blood ammonia levels was far less and of shorter duration than when the blood was given. This same pattern is repeated in all of the patients; that is, for an equivalent amount of protein administered the increase in the levels of blood ammonia was much less marked when Protenum ${ }^{\circledR}$ 


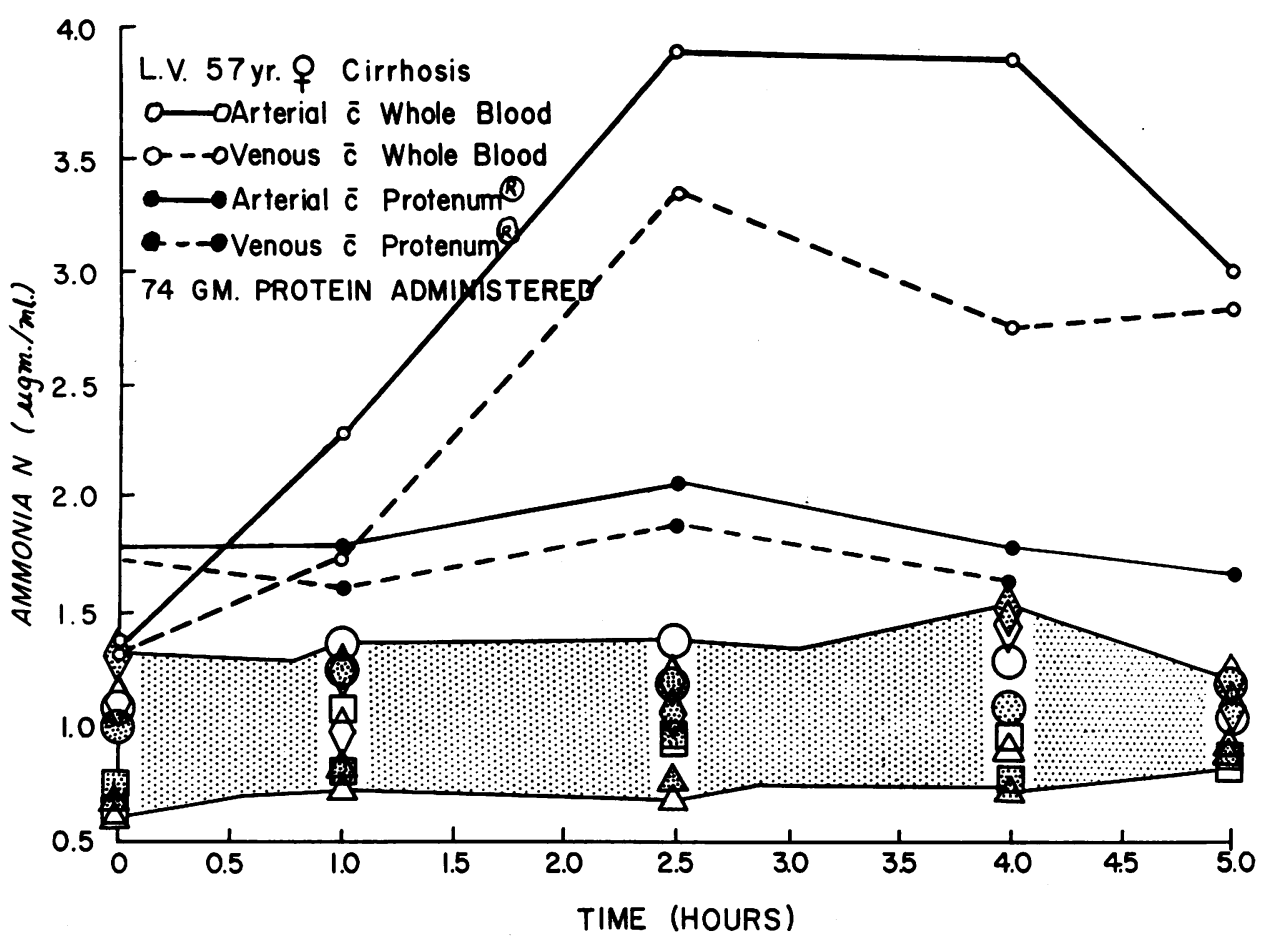

Fig. 2. Blood Ammonia Levels of Typical Patient with Cirrhosis after Administration of Blood and Protenum ${ }^{\circledR}$

Shaded area represents maximum and minimum arterial and venous blood ammonia levels

was given than when blood was given. None of the patients demonstrated any signs or symptoms of disturbance of central nervous system following Protenum ${ }^{\circledR}$ administration. In some patients the changes in the levels of blood ammonia were minimal.
Figure 1 illustrates in graphic form the average arterial and venous levels of ammonia over the five hour test period for the patients with liver disease following both Protenum ${ }^{\circledR}$ and blood administration. The shaded area across the bottom represents maximum and minimum levels of the

TABLE V

Nonprotein nitrogen (NPN) levels following blood and Protenum ${ }^{\circledR}$ administration (mg. per cent)

\begin{tabular}{|c|c|c|c|c|c|c|c|c|c|c|c|c|}
\hline \multirow[b]{2}{*}{ Patient } & \multicolumn{2}{|c|}{$\begin{array}{l}\text { Protein received } \\
(\mathrm{Gm} .)\end{array}$} & \multicolumn{2}{|c|}{ Fasting } & \multicolumn{2}{|c|}{1 hour } & \multicolumn{2}{|c|}{2.5 hours } & \multicolumn{2}{|c|}{4 hours } & \multicolumn{2}{|c|}{5 hours } \\
\hline & Blood Prot & num ${ }^{\circledR}$ & Blood Pro & tenum $®$ & Blood P & rotenum ${ }^{\circledR}$ & Blood Pr & otenum ${ }^{\circledR}$ & Blood Pr & rotenum ${ }^{\circledR}$ & Blood Pro & tenum $\AA$ \\
\hline \multicolumn{13}{|c|}{ A. Patients with no liver disease } \\
\hline $\begin{array}{l}\text { A. R. } \\
\text { M. K. } \\
\text { R. Mc. }\end{array}$ & $\begin{array}{l}63 \\
86\end{array}$ & $\begin{array}{r}70 \\
86 \\
120\end{array}$ & 58.50 & $\begin{array}{l}18.52 \\
33.22 \\
28.20\end{array}$ & 49.50 & $\begin{array}{l}22.72 \\
29.77 \\
33.27\end{array}$ & 52.50 & $\begin{array}{l}23.10 \\
34.05 \\
29.85\end{array}$ & 54.00 & $\begin{array}{l}20.05 \\
33.22 \\
34.42\end{array}$ & 54.00 & 18.97 \\
\hline \multicolumn{13}{|c|}{ B. Patients with liver disease } \\
\hline $\begin{array}{l}\text { F. S. } \\
\text { F. G. } \\
\text { L. V. } \\
\text { R. S. } \\
\text { R. V. } \\
\text { E. B. } \\
\text { C. D. }\end{array}$ & $\begin{array}{r}103 \\
104 \\
74 \\
80 \\
75 \\
80 \\
70\end{array}$ & $\begin{array}{r}91 \\
120 \\
74 \\
80 \\
75 \\
80 \\
70\end{array}$ & $\begin{array}{l}19.72 \\
12.45 \\
20.77 \\
20.77 \\
15.00 \\
17.20 \\
21.60\end{array}$ & $\begin{array}{l}20.02 \\
13.37 \\
21.22 \\
33.30 \\
21.22 \\
17.90 \\
25.45\end{array}$ & $\begin{array}{l}23.47 \\
19.95 \\
24.52 \\
38.70 \\
19.72 \\
25.80 \\
36.22\end{array}$ & $\begin{array}{l}22.57 \\
17.65 \\
19.95 \\
33.75 \\
25.35 \\
19.51 \\
28.28\end{array}$ & $\begin{array}{l}32.10 \\
22.05 \\
32.85 \\
39.52 \\
22.50 \\
29.70 \\
35.40\end{array}$ & $\begin{array}{l}20.02 \\
18.75 \\
21.22 \\
33.30 \\
24.15 \\
20.83 \\
25.04\end{array}$ & $\begin{array}{l}26.40 \\
22.87 \\
44.47 \\
47.47 \\
27.60\end{array}$ & $\begin{array}{r}17.02 \\
17.65 \\
9.50 \\
35.40 \\
24.15\end{array}$ & $\begin{array}{l}23.47 \\
10.35 \\
29.55 \\
52.05 \\
25.20 \\
34.60\end{array}$ & $\begin{array}{l}36.15 \\
18.30 \\
23.32 \\
41.25\end{array}$ \\
\hline Average & 84 & 84 & 18.21 & 21.78 & 26.91 & 23.86 & 30.58 & 23.33 & 33.16 & 20.74 & 29.20 & 25.23 \\
\hline
\end{tabular}


normals. Figure 2 shows the results of one typical patient, L. V., with the normal range again shaded in.

Table V gives the levels of NPN on the same patients. The rise in NPN's tended to parallel the changes in blood ammonia.

\section{DISCUSSION}

The patients chosen for evaluation in the study were known cirrhotics (six out of seven) of fairly long standing, neither convalescing from an acute episode nor noticeably deteriorating. In a group of patients who are thought to have clinically equivalent liver disease the liver function test may differ markedly from patient to patient. Conversely, although biochemically the same, two cirrhotic patients may appear very different clinically. Therefore it was felt that comparison of one group of patients with another group of patients would not yield as valid or worthwhile information as would the comparison of each patient with himself at relatively short intervals.

The total amount of protein administered in the form of blood and Protenum ${ }^{\circledR}$ was the same for both test substances (with the exceptions noted above) for a given subject. However, all subjects did not receive the same total amount of protein. An attempt was made to vary the dose of total protein from patient to patient according to an estimate of the severity of each individual's liver disease in order to avoid precipitating hepatic coma. Despite this variation in dosage, all patients showed the same pattern of response, i.e., all had a greater rise in blood ammonia after ingestion of blood than after Protenum ${ }^{\circledR}$ ingestion.

The average ammonia level of the bank blood administered was $10 \mu \mathrm{g}$. per ml. If a total of 500 $\mathrm{ml}$. of blood was given (and this was the average amount administered), the total ammonia given would be $5 \mathrm{mg}$., roughly equivalent to $20 \mathrm{mg}$. of ammonium chloride. This amount of ammonia distributed unaltered throughout the body fluids would cause an increase of $0.125 \mu \mathrm{g}$. per $\mathrm{ml}$. in a 70 kilogram individual. This is an insignificant amount even though it has been remarked upon by Spear, Sass, and Cincotti (11). We therefore feel that the free ammonia in the bank blood did not contribute to the marked elevations of the blood ammonia levels noted following ingestion of blood. The average level of ammonia in Protenum ${ }^{\circledR}$ was $6 \mu \mathrm{g}$. per $\mathrm{ml}$. Further evidence that the ammonia in transfused blood is negligible in effect can be obtained from the data of Gorten, Shear, Hodson, and Bessman (12) concerning the use of fresh blood for exchange transfusion. Here it is shown that blood with an ammonia content of up to $3 \mu \mathrm{g}$. per $\mathrm{ml}$. had no effect in the blood ammonia level of the recipient, even though more than ninety per cent of the patient's blood was exchanged.

An uptake of ammonia both by cerebral and peripheral tissues has been demonstrated by Bessman, Fazekas, and Bessman $(13,14)$. In this study a correlation between arteriovenous differences (i.e., uptake of ammonia by the tissues) and the degree of elevation of the arterial ammonia was observed. In general, the greater the elevation of arterial blood ammonia, the greater the arteriovenous difference. These observations have been confirmed by some (15) and disputed by others (16). Even in this latter report, however, the data in Figure 6 appear to show a similar correlation. Six of the seven patients with liver disease in the present study showed correlation of arteriovenous difference of ammonia with a rise in the arterial levels. One patient (R. S.) showed no difference whatsoever, even on pronounced elevation of the arterial level. This patient was extremely thin and his muscle mass greatly reduced. It may be that in certain conditions such as extreme debility or cachexia, capacity of muscle for removing ammonia has already been reached and no increased activity is possible. Terminal coma patients have been observed to have a similar reversal of arteriovenous differences (17). This phenomenon is not consistent, nor is it explicable at the present time.

The deleterious effects of gastrointestinal bleeding in patients with cirrhosis have long been known. Welch, Kiley, Reeve, Goodrich, and Welch (1) reported a 76 per cent mortality in patients with cirrhosis during their first hemorrhage. Over 90 per cent of these patients had proven varices. The presence of cirrhosis in a patient with a bleeding duodenal ulcer makes for a more guarded prognosis (2). Some of these deaths are attributable, of course, to uncontrollable hemor- 
rhage. However, patients with severe liver disease can be precipitated into hepatic coma by gastrointestinal bleeding. In a series recently reported by Summerskill, Wolfe, and Davidson (5), gastrointestinal hemorrhage precipitated or complicated hepatic coma in 12 of 34 patients.

Young, Burnside, Knowles, and Schiff (7) have shown that patients with liver disease given $500 \mathrm{ml}$. of bank blood show a far greater rise in blood ammonia levels than do normal controls. In this study, one pint of blood was administered without the amount of total nitrogen in that specimen having been determined. Our measurements have shown that one pint of blood may contain from 62 to $136 \mathrm{Gm}$. of protein. Other investigators have shown elevations in blood ammonia levels following administration of ammonium chloride, urea and high protein feedings $(3-6,18)$. These changes would seem to be of the same order of magnitude as those shown by Young and coworkers following blood administration. Furthermore, it has been reported that diets of $120 \mathrm{Gm}$. of protein may precipitate coma in patients with cirrhosis and that occasionally patients have been sensitive to as little as $20 \mathrm{Gm}$. of protein (5). Patients so sensitive to dietary protein (if it can be likened to Protenum ${ }^{\circledR}$ ) would probably be inordinately sensitive to blood in the gastrointestinal tract.

The present study has shown that per Gm. of nitrogen administered, ingested blood causes a higher level of blood ammonia than protein from a casein and milk solids source. Certain amino acids such as methionine (19) have been shown to be particularly toxic in patients with liver disease, probably through their effect on blood ammonia. Others, such as glutamic acid and arginine, have been shown to have protective properties in preventing ammoniagenic coma or in ameliorating its symptoms when such symptoms are precipitated by a sudden ingestion of substances previously mentioned (blood, ammonium chloride, urea, and so forth). One of the problems now under study is whether blood contains more of the toxic amino acids or whether Protenum ${ }^{\circledR}$ contains more of the protective ones.

Certain practical therapeutic considerations follow from the above study. In the treatment of gastrointestinal hemorrhage in patients with liver disease several procedures would seem advisable in addition to the usual ones of blood replacement, treatment of shock, and so on. These studies would support the views of those who advocate removal of the blood from the gastrointestinal tract by aspiration and the use of enemas (5). The rationale of the use of antibiotics such as chlortetracycline (19) and neomycin (20) rests on the inhibition of enteric bacterial flora which increase proteolysis. Certainly the administration of one of these drugs would be advisable in the treatment of gastrointestinal hemorrhage in patients with liver disease.

The adjuvant use of sodium glutamate and/or arginine is also indicated in the treatment of ammoniagenic coma precipitated by gastrointestinal bleeding in patients with liver diseases. Various investigators have used glutamate in the therapy of hepatic coma with varying reports as to its success or failure (21-24). However, even in those instances in which the patient did not respond clinically, the blood ammonia levels usually fell during or shortly after glutamate administration. Other workers have used arginine $(25,26)$ to lower blood ammonia levels. In a recent study it was shown that in cirrhotic patients glutamate was more effective than arginine, mole for mole, in preventing the elevation of blood ammonia produced by administration of ammonium chloride (27).

The observation has been made that in conditions such as gastrointestinal hemorrhage, shock, and so forth, there exists a state known as prerenal azotemia, characterized, among other things, by an oliguria and an elevated NPN. These abnormal findings usually return to normal with the correction of the primary lesion. In the present study, as well as in the observations of Young and associates (7), the rise of the NPN paralleled the rise of the blood ammonia. In no case in which the blood ammonia levels remained stationary did the NPN levels increase; and conversely, in no cases in which the ammonia levels rose did the NPN levels fail to rise. Nelson and Seligson (28) have shown blood ammonia levels to be elevated in shock, and this study as well as others has shown the blood ammonia levels to be elevated by the presence of blood in the gut. Thus it may be that a part of the elevated NPN which 
characterizes prerenal azotemia may be due to the presence of elevated blood ammonia, which furnishes a source for the rapid synthesis of urea, glutamine and other components of the nonprotein nitrogen.

\section{CONCLUSIONS}

1. Blood and a casein-milk solids preparation (Protenum ${ }^{\circledR}$ ) were administered intragastrically to control patients and patients with liver disease. Each patient received both test substances and for a given patient the total nitrogen content of the two test substances was the same.

2. None of the control subjects showed significant elevations in either blood ammonia or the nonprotein nitrogen $(\mathrm{NPN})$ over a period of three to five hours.

3. All seven of the patients with liver disease showed a significant rise in blood ammonia and NPN following administration of blood; six of these patients showed a significant rise in these determinations following the administration of Protenum ${ }^{\circledR}$. In the patients with liver disease, ammonia and NPN levels following administration of blood were uniformly higher than following Protenum ${ }^{\circledR}$.

4. Several patients developed central nervous system symptoms during the period of elevation of blood ammonia levels.

5. The arteriovenous difference of ammonia increased in six of the seven patients with liver disease as the arterial levels increased.

6. The practical significance of these findings in relation to the treatment of gastrointestinal hemorrhage is discussed.

\section{REFERENCES}

1. Welch, C. S., Kiley, J. E., Reeve, T. S., Goodrich, E. O., and Welch, H. F. Treatment of bleeding from portal hypertension in patients with cirrhosis of the liver. New Engl. J. Med. 1956, 254, 493.

2. Smythe, C. McC., Osborne, M. P., Zamcheck, N., Richards, W. A., and Madison, W. M., Jr. Bleeding from the upper gastrointestinal tract. An analysis of 111 cases. New Engl. J. Med. 1957, 256, 441.

3. Phillips, G. B., Schwartz, R., Gabuzda, G. J., Jr., and Davidson, C. S. The syndrome of impending hepatic coma in patients with cirrhosis of the liver given certain nitrogenous substances. New Engl. J. Med. 1952, 247, 239.
4. McDermott, W. V., Jr., and Adams, R. D. Episodic stupor associated with an Eck fistula in the human with particular reference to the metabolism of ammonia. J. clin. Invest. 1954, 33, 1.

5. Summerskill, W. H. J., Wolfe, S. J., and Davidson, C. S. The management of hepatic coma in relation to protein withdrawal and certain specific measures. Amer. J. Med. 1957, 23, 59.

6. Webster, L. T., Jr. Ammonium metabolism. Amer. J. Med. 1956, 21, 130.

7. Young, P. C., Burnside, C. R., Knowles, H. C., Jr., and Schiff, $L$. The effects of intragastric administration of whole blood on the concentration of blood ammonia in patients with liver disease. $\mathrm{J}$. Lab. clin. Med. 1957, 50, 11.

8. Hiller, A., Plazin, J., and Van Slyke, D. D. A study of conditions for Kjeldahl determination of nitrogen in proteins. Description of methods with mercury as catalyst, and titrimetric and gasometric measurements of the ammonia found. J. biol. Chem. 1948, 176, 1401.

9. Seligson, D., and Seligson, H. A microdiffusion method for the determination of nitrogen liberated as ammonia. J. Lab. clin. Med. 1951, 38, 324.

10. Gradwohl, R. B. H. Clinical Laboratory Methods and Diagnosis, 5th ed. St. Louis, C. V. Mosby Co., 1956, vol. 1, p. 244.

11. Spear, P. W., Sass, M., and Cincotti, J. J. Ammonia levels in transfused blood. J. Lab. clin. Med. 1956, 48, 702.

12. Gorten, M. K., Shear, S., Hodson, M., and Bessman, S. P. Complications of hyperbilirubinemia in the newborn-possible relation to the metabolism of ammonia. Pediatrics 1598, 21, 27.

13. Bessman, S. P., Fazekas, J. F., and Bessman, A. N. Uptake of ammonia by the brain in hepatic coma. Proc. Soc. exp. Biol. (N. Y.) 1954, 85, 66.

14. Bessman, S. P., and Bessman, A. N. The cerebral and peripheral uptake of ammonia in liver disease with an hypothesis for the mechanism of hepatic coma. J. clin. Invest. 1955, 34, 622.

15. Bessman, S. P., and Bradley, J. E. Uptake of ammonia by muscle. Its implications in ammoniagenic coma. New Engl. J. Med. 1955, 253, 1143.

16. Summerskill, W. H. J., Wolfe, S. J., and Davidson, C. S. The metabolism of ammonia and $\alpha$-ketoacids in liver disease and hepatic coma. J. clin. Invest. 1957, 36, 361.

17. Bessman, A. N., and Mirick, G. S. Unpublished observations.

18. Schwartz, R., Phillips, G. B., Seegmiller, J. E., Gabuzda, G. J., Jr., and Davidson, C. S. Dietary protein in the genesis of hepatic coma. New Engl. J. Med. 1954, 251, 685.

19. Phear, E. A., Ruebner, B., Sherlock, S., and Summerskill, W. H. J. Methionine toxicity in liver disease and its prevention by chlortetracycline. Clin. Sci. 1956, 15, 93. 
20. Fisher, C. J., and Faloon, W. W. Blood ammonia levels in hepatic cirrhosis: Their control by oral administration of neomycin. New Engl. J. Med. 1957, 256, 1030.

21. Walshe, J. M. The effect of glutamic acid on the coma of hepatic failure. Lancet 1953, 1, 1075.

22. McDermott, W. V., Jr., Wareham, J., and Riddell, A. G. Treatment of "hepatic coma" with l-glutamic acid. New Engl. J. Med. 1955, 253, 1093.

23. Webster, L. T., Jr., and Davidson, C. S. The effect of sodium glutamate on hepatic coma. J. clin. Invest. 1956, 35, 191.

24. Iber, F. L., and Chalmers, T. C. Biochemical observations on the use of L-glutamic acid in treat- ment of hepatic coma. J. clin. Invest. 1957, 36, 706.

25. Najarian, J. S., and Harper, H. A. A clinical study of the effect of arginine on blood ammonia. Amer. J. Med. 1956, 21, 832.

26. Fahey, J. L., Nathans, D., and Rairigh, D. Effect of L-arginine on elevated blood ammonia levels in man. Amer. J. Med. 1957, 23, 860.

27. Bessman, S. P., Shear, S., and Fitzgerald, J. The effect of arginine and glutamate on the removal of ammonia from the blood in normal and cirrhotic patients. New Engl. J. Med. 1957, 256, 941.

28. Nelson, R. M., and Seligson, D. Studies on blood ammonia in normal and shock states. Surgery 1953, 34, 1. 